\title{
Personal Injury Law Reform: a Proposed First Step
}

\author{
by Stephen D. Sugarman*
}

\section{Introduction and overview}

As a system for compensating victims, personal injury law in Britain is badly failing. First, large numbers of accident victims receive nothing from the tort system. Second, even when it does provide compensation, tort law typically takes far too long and costs entirely too much to do so.

This indictment of personal injuries law has been well understood for some time. Professor Terrence Ison's powerful critique, titled "The Forensic Lottery," was published in 1967. Ison's criticisms were renewed and further documented both by the Report of the Pearson Commission $^{1}$ in 1978 and more recently by Donald Harris and his colleagues at Oxford's Centre for Socio-Legal Studies in "Compensation and Support for Illness and Injury" (1984).

Each of these reviews has proposed replacing some or all of personal injury law with a new system of victim compensation that would not depend upon fault and would be paid both promptly and largely without the involvement of lawyers. Yet no major reform of British tort law has occurred.

Perhaps concluding that the introduction of a new compensation scheme, whatever its merits, is simply politically infeasible in the near future, the Lord Chancellor recently launched a new effort termed the Civil Justice Review, and the improvement of personal injuries litigation in England and Wales has been at the heart of its mission. Yet the scope of the Review extends only to reforms in jurisdiction, procedure and court administration. ${ }^{2}$ To advise him in connection with the Review, the Lord Chancellor created an independent committee, chaired by Sir Maurice Hodgson, and in February 1986 a Consultation Paper on personal injuries litigation was issued. It was based upon the deliberations of this committee as assisted by a factual study carried out for the Review by Inbucon Management Consultants. ${ }^{3}$

The Civil Justice Review's Consultation Paper once again identified excessive costs and unacceptable delays as two key problems in the

\footnotetext{
* Professor of Law, University of California, Berkeley.

${ }^{1}$ Royal Commission on Civil Liability and Compensation for Personal Injury, Cmnd.7054 (1978) (the "Pearson Report").

2 The Review is to consider small claims, debt, housing and commercial cases as well. See Civil Justice Review, Personal Injuries Litigation Consultation Paper (February 1986) at p.4 ("Consultation Paper"). Personal injuries were the first subject considered by the Review.

${ }^{3}$ This study "Civil Justice Review Study of Personal Injuries Litigation" was published by the Lord Chancellor's Department simultaneously with the consultation paper.
} 
functioning of personal injuries litigation under the current regime. It showed, for example, that it is often three years or more from the date of the accident to the conclusion of litigation even in small cases brought in the County Court (which has jurisdiction over claims up to $£ 5,000$ ); and often six or more years elapse before a final resolution of the typically more serious injury cases brought in the High Court. ${ }^{4}$ As for costs, the Inbucon study demonstrated that in the County Courts more than a pound is spent on legal costs for every pound of damages won by plaintiffs; and even in High Court cases, costs add $£ 50$ or $£ 70$, depending upon the basis of calculation, to every $£ 100$ of damages awarded. ${ }^{5}$

To deal with these problems, the Consultation Paper concluded that "radical changes in procedure, jurisdiction and forensic methods" are needed ${ }^{6}$ and proposed a series of thoughtful, sometimes provocative, reforms of existing arrangements. ${ }^{7}$ I am not going to describe or review such proposals here, however, and will limit myself to two comments about them.

First, even if the highest hopes of the Consultation Paper were realised, there would still be considerable legal expenses incurred in the disposition of personal injury claims and there would still be delays between the time of an injury and the award of compensation. This is because, even under the proposed procedural streamlining, every case would continue to require an individualised determination (or agreed settlement) of both legal liability and the amount of damages to be awarded. Second, since the Consultation Paper shies away from any expansion in liability, the great bulk of accident victims would continue to go uncompensated by tort law. ${ }^{8}$ In short, without in the least doubting that the current system can be made more efficient, one must say that the approach of the Consultation Paper necessarily leaves fundamental problems unsolved.

Bolder reform is needed, and my purpose in this article is to put forward an alternative plan. It is designed to promote, in a far more effective way, what I see as the underlying goals of the Civil Justice Review with respect to personal injuries litigation-both the prompt payment of victim compensation at little administrative cost and the

\footnotetext{
4 Consultation Paper at p.34.

5 lbid.

6 Id. at p.36.

7 Id. at Chapters 5 and 6.

${ }^{8}$ The Consultation Paper, id. at p.7, admits that probably no more than 10 per cent. of accident victims now seek tort remedies. The other 90 per cent. include people who are unaware of their legal rights, those who don't realise that they were the victims of negligence, those who are unable to prove another's fault owing to missing evidence, and those who choose not to pursue their legal rights for fear that the experience of litigation will be more harmful than it is worth. All of these victims are meant to be compensated by tort law, but aren't. In addition, of course, the tort system doesn't even intend to provide help for all those accident victims who, although equally in need of compensation, were hurt in ways for which no other party has legal responsibility-basically through either no one else's fault or solely because of their own fault.
} 
unclogging of the courts. It also attacks the deeper problem of providing compensation to those who are outside the tort system entirely. Mindful, however, of the fate of the ambitious reform ideas mentioned earlier, my proposal does not rely upon the introduction of a new compensation plan of the sort recommended by Ison, Pearson and the Oxford group.

My basic strategy is to try to rid the litigation process of a large proportion of the smaller personal injury cases it now handles on terms that are fair to victims. The sensible way to achieve this, as I see it, involves making two sorts of changes. First, independent of the tort system, yet based upon existing benefit arrangements, no fuss protection against out-of-pocket losses has to be assured to those people with modest injuries. The key to my proposal is a moderate extension of the recently adopted Statutory Sick Pay plan, about which I will say more shortly. Enacted after Ison, Pearson and the Oxford group formulated their proposals, this in-place scheme provides a ready base upon which an adequate income replacement benefit for the temporarily disabled could be built.

Second, once compensation for basic out-of-pocket losses is reasonably assured to tort victims with relatively small injuries, I propose the adoption new legal hurdles that are meant to discourage large numbers of them from filing suit. Shortly I will outline alternative forms that these hurdles might take. They all rest on my belief that it is socially undesirable to incur the large transactions costs, as happens now, in order to provide tort victims with modest cash awards in compensation for the pain and suffering they have endured.

The result of my proposed reforms should be that many torts cases litigated in the County Courts under today's system would not be brought at all (or else would be settled much more quickly). Many High Court cases too should disappear or be transferred to the County Courts. With many fewer disputes to handle, the administrative costs of the personal injury system would be substantially reduced; and those remaining expenditures would be concentrated on the more serious injury cases.

In short, I envision what ought to be a politically attractive trade: the critical needs of most victims of temporarily disabling accidents (and indeed of short term illness as well) would be promptly and efficiently taken care of; and, in return, large numbers of not seriously injured tort victims would forgo their claims for damages that don't refiect out-of-pocket losses.

Tort victims with serious and longer term injuries could still look to the litigation process to compensate for their losses and on terms not significantly changed from the present. Ultimately, these people too should be dealt with in other ways-which is why I term my proposal 
a "first step." But these expensive cases, as important as they are, are the minority in terms of numbers. And at least there is a chance that they would receive quicker attention if much of the small personal injury caseload were taken out of the litigation process.

Whether or not my proposal is actually within the scope of the Review won't concern me here; plainly, the Government could elect to adopt it.

The two sections that follow set out in more detail my recommendations for enhanced victim compensation and reduced litigation. Thereafter, I address the financing of my proposed reform and some questions about behavioural incentives. Finally, I consider the likely reactions to my proposal by various interest groups.

\section{Improving the compensation of victims}

Certainly for those people who are only temporarily disabled, the main social goals ought to be to assure (1) that they receive medical services that enable them promptly to return to their normal activity and (2) that their ordinary earnings are largely and quickly replaced during this period of incapacity.

The receipt of appropriate medical care is already meant to be guaranteed in Britain by the National Health Service (or alternatively through private health care insurance that some people have). To the extent that the National Health Service ("N.H.S.") might currently be failing in certain respects to provide needed medical services to the temporarily disabled, this surely calls for the strengthening of the N.H.S. itself, rather than having those services provided privately only to the lucky few who are financed by tort awards. Therefore, for my purposes here, I will assume that tort law in Britain has no important compensatory function to play with regard to paying for the medical needs of those victims who don't have long term disabilities. ${ }^{9}$

By contrast, many people who today suffer a temporary disability plainly have inadequate income support arrangements. For people who are either injured or become ill, and are employed at the time, the basic governmental programme here is the Statutory Sick Pay scheme ("S.S.P."). ${ }^{10}$ Introduced in 1983 and already extended once, S.S.P. now guarantees all temporarily disabled employees, after a three-day waiting period, up to 28 weeks of cash assistance ${ }^{11}$ (after which time someone who is still disabled is meant to switch over to

\footnotetext{
9 The long term disabled often have substantial ongoing needs arising out of their disabilities that are not the responsibility of the N.H.S., and which, alas, are often inadequately served. But the long term disabled, as already noted, are not my focus here.

${ }_{10}$ Social Security and Housing Benefits Act 1982 effective from April 1983. S.S.P. was proposed in 1980. See D.H.S.S., Income During Initial Sickness: A New Strategy, Cmnd.7864 (1980).

$"$ Pursuant to the Social Security Act 1985, S.S.P.'s cover was expanded from 8 to 28 weeks as of April 1986.
} 


\section{Stephen D. Sugarman}

one of the long-term disability schemes). S.S.P. has largely replaced the Sickness Benefit formerly provided by the National Insurance system, as well as the short-term income replacement benefit formerly provided by the Industrial Injuries scheme. Part of the Conservative Government's "privatisation" effort, ${ }^{12}$ S.S.P. is administered by employers, who are, in turn reimbursed for their benefit costs by reduced contributions to the National Insurance system.

Although the durational feature of S.S.P. is now quite adequate and although the waiting period is not too burdensome, the problem is that the benefit is too low, currently amounting to only $£ 46.75$ per week for most employees (and even less for those earning less than $\mathfrak{f} 74.50$ per week). ${ }^{13}$ As explained by the Disability Alliance and others, "In April 1984, the highest rate of S.S.P. represented 24 per cent. of the average male weekly earnings and 36 per cent. of average female weekly earnings. In Germany, by comparison, all employees receive full pay from their employer for the first 6 weeks of sickness, followed by 80 per cent. of full pay from the government." 14

The inadequacy of the existing S.S.P. benefit is underlined by the fact that a large portion of British workers (probably three-quarters) have substantial supplementary sick pay arragements provided through their work, usually called Occupational Sick Pay plans ("O.S.P."). ${ }^{15}$ These schemes top up the S.S.P. benefit, thereby providing employees with the needed funds. ${ }^{16}$

But since many people do not have an O.S.P. benefit available to them, if they are temporarily disabled their income can take a severe dip. And if their disability is caused by the fault of another, they have

\footnotetext{
${ }^{12}$ See e.g. O'Higgins, "Income During Initial Sickness: An Analysis and Evaluation of a New Strategy for Social Security," 9 Policy and Politics 151 (1981) and O'Higgins, "Privatisation and Social Security," 55 Political Quarterly 129 (1984).

${ }_{13}$ As of May 1986.

14 Disability Alliance and others, Statutory Sick Pay: The failure of privatisation in social security (1986) at p.9

15 A 1974 government survey showed that 80 per cent. of fulltime male employees and 77 per cent. of fulltime female employees were then covered by an O.S.P. plan. For various reasons, such as not having worked a sufficient qualifying period, the share of workers actually eligible for O.S.P. payments was less -71 per cent. Moreover, not all of the O.S.P. plans provided full or nearly full wage replacement. See Statutory Sick Pay, id. at pp.12-13 and sources cited therein. On the other hand, it seems generally agreed that O.S.P. coverage has grown since this 1974 survey. For example, recently the Social Security Policy Inspectorate reported on a small survey it carried out subsequent to the introduction of S.S.P. that examined, among other things, the availability of O.S.P. See Social Security Policy Inspectorate, Enquiry Into Statutory Sick Pay (1985). For various reasons the Policy Inspectorate deliberately sought an overrepresentation of small employers and their employees in the sample interviewed. See id. at Chapter 1 . Even so, 78 per cent. of those interviewed "told us they received some form of sick pay." Id. at para. 2.3. Moreover, in the "A" portion of the sample, which seems more broadly to reflect employees generally, the proportion covered by a formal O.S.P. scheme was 89 per cent. $I d$. at para. 1.19 Of course, in some cases O.S.P. benefits may be quite meagre; and, once again, the fact that an employer has a plan does not mean that all of its employees will actually obtain sick pay benefits. On this data I base my estimate that probably three-quarters of employees are now reasonably well protected by O.S.P. plans.

${ }_{16}$ In many O.S.P. plans, benefits are paid from the first day of disability, that is, without a waiting period.
} 
good reason to sue in tort in order to make up the shortfall. In order to make up this deficit, and in turn to take away the need for many people to resort to litigation, I propose a further enhancement of S.S.P. The Government should assure that all employees earning up to, say, twice the average industrial wage, ${ }^{17}$ are eligible for benefits equal to at least $80-90$ per cent. of their pre-disability income. I use the 80-90 per cent. figure, rather than full pay, because those off work will typically save their normal work-related expenses, such as commuting costs.

Because the basic S.S.P. plan is now in place and functioning reasonably well, ${ }^{18}$ the benefit extension I propose could be easily implemented. The Government could simply mandate that, instead of the current award levels, employers must provide the more generous wage replacement benefit described above.

It is critical to appreciate that for many employers my proposal would essentially codify their existing practices; a large proportion of O.S.P. plans already provide six months of benefits and pretty much maintain the disabled worker in full pay status. ${ }^{19}$ Indeed, some employers would presumably continue to operate their existing O.S.P. plans that are even more generous than would be required by the enhanced S.S.P. scheme I propose. But, at the same time, in work settings where there is no O.S.P. plan or only a modest one now in place, this change would be a considerable improvement for the temporarily disabled, including, of course, many employees who are modestly injured tort victims. ${ }^{20}$ It also bears re-emphasising that an improved S.S.P. benefit will help people who are temporarily disabled through illness as well as those who suffer injuries from accidents; indeed, I assume that accident victims are a minority of those who claim S.S.P. today. ${ }^{21}$

\footnotetext{
${ }^{17}$ I see no strong social policy reason to insist that such high a wage replacement rate be guaranteed to that small proportion of the workforce earning more than the ceiling envisioned. Moreover, such people are very likely to have generous arrangements already in place, either through their work or through private insurance.

${ }^{18}$ See e.g. D.H.S.S. Press Notice, "Chancellor's Statement: Social Security," November 12, 1984. For a vigorous criticism of S.S.P.'s operation, especially in relation to low earners, see Statutory Sick Pay, supra, note 14.

${ }_{19}$ For example, the Social Security Policy Inspectorate, supra, note 15 at para. 2.9, apparently found that about 60 per cent. of those employees who knew about the duration of their O.S.P. plan said its benefits lasted either "up to 26 weeks" or "for 26 weeks or more." (Unfortunately, the Policy Inspectorate doesn't give durational details reported by its other interviewees.) Moreover, more than 88 per cent. of those who had O.S.P. protection and were reported as knowing about the level of its benefits said they received their normal pay while sick. Id. at Table 5, para. 2.5.

${ }^{20}$ The survey by the Social Security Policy Inspectorate, supra, note 15 at Table 5 para. 2.5 , showed that those in occupations classed as "industrial," "transport," "catering" and "construction" stand to gain most from my proposal; whereas those whose occupations are classed as "public employees," "managerial, administrative and clerical" and "sales" are shown to be well covered by O.S.P. already.

${ }^{21}$ I have been unable to find direct evidence on this point. The Oxford survey, however, found that "illness causes much more incapacity than accident, both in terms of the numbers of people affected, and the length and severity of the consequences. ... Illness, on average, also causes absences from work which last more than twice as long as absences caused by accidents." D. Harris et al, Compensation and Support for Illness and Injury (1984) at pp.326-327.
} 
Improving S.S.P. admittedly does nothing for those people who are not employed at the time they are temporarily disabled. They include children and students, the retired, the unemployed, and homemakers ("housewives"). But these people typically have no earnings loss for the tort law to reimburse either. ${ }^{22}$ Their needs for income will continue to be met, or not met in some cases, through other mechanisms. ${ }^{23}$

If personal injury victims are able to turn to other sources to replace up to 28 weeks of lost income and to have their medical needs taken care of, then tort law should not also be used as a source of funding for these losses. More precisely, I firmly believe that victims should not be able to duplicate through personal injury litigation their recovery from either S.S.P. or O.S.P. Nor do I think it would be socially useful to permit people to claim in tort for any shortfall in their income that arises either because of S.S.P.'s threeday waiting period ${ }^{24}$ or because under my proposal S.S.P. would replace only $80-90$ per cent. rather than 100 per cent. of previous earnings. ${ }^{25}$ Moreover, I think a good case can be made that well-off people with earnings above the S.S.P. maximum that I have recommended can be fairly left to look out for their own temporary income losses. ${ }^{26}$

\footnotetext{
${ }^{22}$ I concede that the unemployed who successfully sue in tort might obtain modest damages in some cases on the theory that their injury precluded them from finding and taking up work during the short term period of disability that I am considering here, but surely this is an advantage that accrues to rather few people. There are some temporarily disabled people who don't qualify for S.S.P. but may still receive the old Sickness Benefit. Were S.S.P. enhanced as I propose, then perhaps the residual Sickness Benefit should be improved as well.

${ }_{23}$ Many would simply continue to receive whatever social security benefit they were receiving before the injury, e.g. retirement pension or supplementary benefit. The main point is that most of the people in these groups simply don't lose earnings because of a temporary disability.

A different problem is that during periods of even temporary disability people sometimes require significant, extra goods or services, especially "home help" services, that are not considered "medical" and hence not the responsibility of the N.H.S. For example, if a person is well enough to leave hospital but yet is sufficiently disabled to need personal care at home, then although the N.H.S. may provide some home nursing services, this may well not suffice for all of the person's special needs. Even more clearly, if a homemaker is disabled, someone else must take on the responsibility of the household chores, and the N.H.S. certainly won't provide someone to do that. Although most people probably don't usually consider it unreasonable for the extra burden of "home help" needs to fall on other household members, or even nearby family and friends, for limited periods of time, it seems to me that six months may often be rather too long to ask people to go without any outside backup. Yet those existing non-contributory cash benefits that can be seen to help with these sorts of needs (e.g. "severe disablement allowance," "invalid care allowance" and "attendance allowance") aren't available until after at least six months of disability. See generally D.H.S.S., Non-contributory Benefits for Disabled People (1985). In general therefore, the temporarily disabled who need home help assistance must turn to social services agencies. I sense, however, that local authorities differ considerably in their willingness and ability to provide for such needs. Thus, this is an area that probably could benefit from some policy review, which, unfortunately, I am unable to provide here. I will note, however, that while tort victims in principle can obtain damages to pay for such services, plainly only a tiny portion of people who need them currently have them paid for in this way.

${ }_{24}$ This is too small an amount for which the tort system should be bothered, and, if not covered by the employer through a supplementary programme, can ordinarily be well absorbed by the employee (e.g. by taking a paid vacation day if necessary).

${ }^{25}$ Since this provision is meant generally to make employees whole in terms of disposable income, any difference in individual cases between presumed and actual work-expenses seems too trivial for the tort system to be concerned about.

${ }^{26}$ If nothing else, this stops tort law from functioning to redistribute income in what would be a highly regressive way.
} 
Furthermore, I do not believe that employers or their insurers should be able to obtain from tort defendants, through the notion of subrogation, reimbursement of the S.S.P. and O.S.P. payments they make. Using tort law to transfer money from the pocket of one insurance or insurance-like fund to another, which is what this would amount to, is administratively very costly and does not, in my view, serve any useful social function. Even if one were to favour so-called "social cost accounting," designed to make activities pay for the injuries and illnesses they cause, this can be better promoted through taxation-in the way that motoring, smoking and drinking (three very large sources of disability) are already taxed.

Therefore, as part of my proposal, I recommend that personal injury law simply not provide damages for the first 28 weeks of income loss. Perhaps this would be best phrased as barring tort claims for lost earnings during any period in which the victim is eligible to receive S.S.P. ${ }^{27}$

The same points apply to medical expenses. Neither should temporarily disabled victims recover in tort for medical expenses paid for by the N.H.S. or private insurance (and for which they, therefore, suffer no out of pocket losses). Nor should private health insurers or the N.H.S. obtain reimbursement in temporary disability cases from tortfeasors (really, their insurers). My proposals on reimbursement would require some change in existing law. ${ }^{28}$

27 Compare the recent Report issued by the National Audit Office that favours the reimbursement of public sources providing benefits to tort victims and argues that "if social security benefits and statutory sick pay [S.S.P.] . . . paid to those entitled to tort damages were reclaimed in full by D.H.S.S., the benefit to the National Insurance Fund and the Exchequer would now be in the region of some $\$ 150$ million per annum." Recovery of Social Security Benefits when Damages in Tort are Awarded, Report by the Comptroller and Auditor General (July 21, 1986 H.M.S.O.) at p.5. In my judgment, a programme designed to seek reimbursement from the insurers of tortfeasors, calculated on a case by case basis, would be an extremely clumsy device for generating public revenues or, what is the same thing, for "privatising" the cost of accidents. If the National Audit Office thinks that motorists as a class, for example, aren't paying their fair share of the social security and S.S.P. costs they generate, then surely, as already noted in the text above, an increase in the road tax or a tax on auto insurance policies would be a far more sensible strategy. Fortunately, the Report's authors recognise that their enthusiasm for reimbursement is not shared by either the Pearson Commission or the D.H.S.S.

${ }_{23}$ Although the matter isn't completely free from doubt, there is a recent High Court decision to the effect that under current law one cannot collect in tort for losses covered by S.S.P. See Hepple and Matthews, Tort Cases and Materials (1985) at pp.354-355. Regarding O.S.P., however, apparently some employers and insurers have sought to characterise the benefits they provide in a way that would permit them under current law to recoup such payments through tort litigation. Moreover, apparently private health insurers are today the real parties in interest in many tort claims for medical expenses. Interview with Professor B. A. Hepple, July 10, 1986. Finally, under current arrangements the N.H.S. now receives about $£ 7$ million annually from insurers of negligent motorists who injure people treated by the Health Service. See Recovery of Social Security Benefits when Damages in Tort are Awarded, supra, note 27, at para. 14.

The Pearson Report (Vol. 1 starting at para. 164) recommended a comprehensive reform to deal with the problem of overlapping and offsetting benefits, only small pieces of which have been adopted. See Hepple and Matthews, id. at pp.352-355. However, as Pearson was more concerned about the coordination of benefits for the long term disabled, rather than couching my reforms in the context of the Pearson recommendations, I have elected here only to make proposals that specifically relate to short term periods of disability. 


\section{Cutting back on litigation for pain and suffering}

Besides paying for income losses and medical needs, the important remaining compensatory function of the existing tort system is to provide money damages for pain and suffering.

While not denying the reality of pain and suffering, I question the propriety of compensation for it with money-at least in the smaller cases. There, by the time the award is made, the pain and suffering is usually but a memory and the victim is back to his or her pre-accident way of life. It is also relevant that, although the existing British social security system does provide extra cash payments to employees who suffer permanent impairments from on-the-job accidents, pain and suffering-like payments are not made for only temporary loss of faculty. ${ }^{29}$

Moreover, it is in the small torts cases, as we have seen, that the legal costs are especially and shockingly large. To be sure, in the past the award of pain and suffering damages might have been justified on the ground that it served to punish the wrongdoer. But in today's world of liability insurance and vicarious liability, the personal punishment weapon is drastically blunted since those who actually pay virtually all personal injury awards are not individuals but rather enterprises. Instead of punishing wrongdoers, everyone's insurance costs go up and the primary beneficiaries appear to be the lawyers.

In sum, in view of the lesser amount of harm involved, the prospect of proportionately greater administrative savings, and the precedent of the the Industrial Injuries scheme, I propose cutting back on the small pain and suffering tort claims.

Of course, some people with relatively small injuries and little or no out of pocket losses already elect not to sue. If S.S.P. were enhanced as I have recommended, that would cause others to make the same choice. And my proposals to bar the recovery in tort of short term income losses and otherwise paid for medical expenses would also push in the same direction. But I don't think these alone will suffice to rid the courts of enough of the smaller pain and suffering cases. Rather, as a quid pro quo for the improvement in S.S.P., such litigation should be more actively discouraged.

A number of different strategies might be employed to this end. A quite straightforward solution would be to adopt the rule that the first, say, $£ 1,000$ (or perhaps $£ 3,000$ ) worth of the victim's pain and suffering damages would not be recoverable in tort. ${ }^{30}$ This might be

\footnotetext{
${ }^{29}$ This benefit is called "industrial disablement benefit." See Hepple and Matthews, supra, note 28 , at p.799. It is the result of special historic reasons that these impairment-based benefits are paid only in cases of job-related disabilities.

${ }^{30}$ In their proposed auto no fault plan for the U.S., Professors Keeton and O'Conncll suggested a monetary minimum for pain and suffering claims of $\$ 10,000$. See Keeton and O'Connell, Basic Protection for the Traffic Victim (1965).
} 
termed a "deductible" or "threshold" approach. Although predicting just how much money a particular victim might recover for pain and suffering can be difficult, nonetheless most victims who were advised that their pain and suffering damages would likely be $£ 1,000$ (or $\mathfrak{f 3 , 0 0 0 )}$ or less, or even a few hundred pounds over the threshold, would no longer see any point in suing for this sort of loss. And since my proposals will reasonably assure that the temporarily disabled have their income and medical needs met, it can be readily seen why many of today's small cases would be dropped. ${ }^{31}$

This prospect may be even better appreciated when it is understood that, as shown by the Consultation Paper, in two-thirds of County Court cases today plainfiffs' total damage awards are $£ 1,500$ or less, and in 91 per cent. of the cases the damage award is $£ 3,000$ or less. ${ }^{32}$ Even in the High Court 29 per cent. of cases lead to awards of $£ 3,000$ less. ${ }^{33}$ Also highly revealing are the findings of the Oxford group based upon questionnaires completed by solicitors in the late 1970 s about the personal injury cases they had handled. The mean amount of damages then obtained was $£ 1,183$, including $£ 973$, on average, for non-pecuniary damages, primarily pain and suffering. ${ }^{34}$

If the idea of a monetary threshold seems too arbitrary, other thresholds are also imaginable. Pain and suffering awards could be denied, for example, to anyone who was disabled less than 28 weeks unless he or she were seriously disfigured. Thus, only those who were incapacitated for long periods or who received the sort of substantial harm (e.g. a facial scar or loss of a limb) that would persist beyond a temporary period of disability, would retain the right to sue for pain and suffering. ${ }^{35}$ Yet another approach is to link the right to sue for pain and suffering to the incurring of some specified amount of

\footnotetext{
${ }^{31}$ A recent study by the Rand Corporation's Institute of Civil Justice found that under American auto no fault laws, where victims also have access to first party benefits for out-of-pocket costs, even modest pain and suffering threshholds, such as incurring $\$ 500$ worth of medical treatment, serve substantially to curtail tort claims. See Hammitt and Rolph, Limiting Liability for Automobile Accidents: Are No-Fault Tort Threshholds Effective? (Institute for Civil Justice, October, 1985.)

32 Consultation Paper id. p.23 (Table 2).

33 Id. at p.24 (Table 2).

${ }^{34}$ Harris et al., Compensation and Support for Illness and Injury (1984) at p.90. The Pearson Report also found that more than half the money paid in tort compensation was for non-pecuniary loss. See Vol. 2, paras. 69, 519-521 and Tables 107 and 108.

${ }_{35}$ The concept of "serious disfigurement" could be left to common law interpretation and the judgment of the trial courts; or it could be more specifically defined by legislation to include certain injuries and their equivalents- - such as loss of an eye or a limb. The latter approach, while giving guidance to the courts in clear cases, would still require some delicate judgment in many circumstances.

In the Oxford study, solicitors reported that the amount awarded took account of some permanent impairment in just under 40 per cent. of the cases they handled. See Harris, supra, note 34 , at p.90. I assume that many of these victims would not be thought seriously disfigured, however, suggesting that probably no more than a quarter of claimants, and likely fewer, would meet this test for pain and suffering awards. I also note that the Oxford survey of victims found that fewer than a quarter were off work for more than six months following their accident. See Harris, id. at p.106, Table 3.8.
} 
medical treatment on the ground that this serves as a proxy for substantial pain and suffering. ${ }^{36}$

A quite different strategy for discouraging the small cases is to limit the amount of legal costs that a defendant could be ordered to pay in personal injury cases to, say, one-third of the damages obtained. The idea here is to end the current legal overkill in which too much money is going into the pockets of their lawyers as compared with the victims. For example, at present, according to the Consultation Paper, in the great proportion of County Court cases in which plaintiffs are successful, the plaintiffs' lawyers are awarded costs well in excess of 50 per cent. of the damages. ${ }^{37}$

There is, I candidly acknowledge, a deliberate ambiguity in the way I have so far phrased this proposal: would plaintiffs' legal costs simply be capped by the one-third figure or would costs in excess of this sum be permitted, but would have to come out of the plaintiff's award? In the end, I am not sure that it matters very much.

Were plaintiffs' legal costs capped, this would have the virtue of clearly holding down the relative size of victims' legal costs as compared with their recoveries. Since lawyers wouldn't be expected to work for free, under this arrangement plaintiff lawyers would have to explain to clients that they could only expect rather limited efforts to be made on their behalf in small recovery cases. This, in turn, would presumably cause the lawyers to recommend either a quick settlement or the withdrawal of the claim altogether. For those with small cases who persevere, the limitation on recoverable legal costs would probably weaken their lawyers' bargaining positions. In turn, this would likely mean that such claimants would, on average, receive by way of settlement less money for their pain and suffering than they do today. But as these sums are arbitrary anyway, I don't find this bothersome. $^{38}$

Under the other rule, lawyers would have to advise clients in small cases that their own award was likely to be eaten into by legal costs if more than a modest effort were made on their case. This would give

\footnotetext{
${ }^{36}$ While the approach that ties the pain and suffering claim to a sum of medical expenses has won adherents in the United States, it would be more difficult to implement in Britain because the N.H.S. apparently doesn't routinely price its services to its patients in this way. Although this approach had been criticised in the United States as providing tort victims with an inducement to incur unneeded medical expenses in order to get above the tort threshold, the empirical study by the Rand Institute mentioned in note 31, supra, suggests that this fear is largely groundless.

37 Consultation Paper $i d$. at pp.29 and 32 . For example, from the Inbucon study of taxed bills it was discovered that in the County Court cases, plaintiffs" costs were overall 98.8 per cent. of the damages awarded (Table 7 on p.29) and that 85.7 per cent. of the cases studied involved costs that were more than 50 per cent. of the plaintiff's compensation (Table 8 on p.29). Questionnaires completed by solicitors showed plaintiffs' costs to be 73 per cent. of plaintiffs' compensation in County Court cases (Table 11 on p.32).

${ }_{38}$ This rule might also cause more claimants to try to handle their claims on their own. The Oxford study found that only 8 per cent. of victims had arranged tort settlements without the involvement of a lawyer-and in general appeared to obtain less money than they would have had they used one. See Harris, supra, note 34 , at p.82.
} 
the victim the choice to pay for greater legal efforts. But here, too, plaintiff self-interest should lead to a diminution in litigation. In short, I believe that either sort of limit on recoverable legal costs would cause a large decrease in personal injury litigation in County Courts and some reduction in the High Court.

By contrast, the one-third limit on legal costs should have little impact on the vigour with which lawyers pursue the relatively infrequent large injury cases. There, plaintiffs' legal costs are now much more commonly only 25 per cent. or less of the damages awarded. ${ }^{39}$ And if this limit proved inappropriate for unusual, pathbreaking, test case litigation or other especially thorny matters, then there could be a special discretionary provision for allowing judges to award extra legal costs in just such rare situations.

Just as I don't currently have a firm view as to which approach to limiting legal costs would be better, I am not now confident whether the strategy of limiting recoverable legal costs is more or less preferable to the strategy of imposing a direct limit on pain and suffering claims. Public debate might reveal the superiority of one or the other. Some people might even favour adopting both sorts of limits.

In any event, were reforms of this sort enacted along with the S.S.P. extension, my expectation is that those people with only temporary disabilities and who don't have large pain and suffering claims would have both less reason and considerably less inclination to turn their injury into a legal battle than they do today. The courts ought to be cleared of a great many small cases, thereby both saving public expense and reducing everyone's liability insurance costs. Yet at the same time, because of the expansion of S.S.P., temporarily disabled victims as a class would be considerably better off.

\section{Financing the changes}

To date, S.S.P. has been intended largely to replace sickness and industrial injury benefits that were previously publicly funded. By contrast, my proposal is perhaps best seen as expanding the provision of generous O.S.P. plans to the entire workforce. As these are now privately funded, ought they not remain so? Moreover, as these additions would benefit not only low wage earners, but, importantly, middle and higher income earners as well, doesn't this too argue for making the plan a compulsory employer-funded benefit rather than a public financed benefit?

To be sure, this solution would impose an added expense on employers who now don't provide generous occupational supplements-at least in the short run. (In the long run there is every

\footnotetext{
${ }^{39}$ See Consultation Paper at pp.29 and 32.
} 
reason to think that employees largely pay for such benefits themselves in the form of lower wages). Yet many would think it fair that employers who haven't been providing adequate benefits be made to do so. Moreover, as a partial offset, the cutbacks in the personal injury system I propose would benefit employers in the form of reduced liability insurance (or self-insurance) costs.

I recognise that mandating employers to pay for the enhanced S.S.P. would run into especially strong objections from small business interests. Perhaps because of the uncertain disability risks that such firms face, the Government should therefore subsidise an insurance plan designed to pay enhanced S.S.P. benefits to employees of small businesses. ${ }^{40}$ This subsidy should also help neutralise the risk that my proposal would stimulate small employers to pressure their workers to become "independent contractors."

As for where the funds for this subsidy would come from, I have three points to make. First, the reduction in personal injuries litigation that my reforms promise ought to yield a savings in legal aid costs; the scale of such savings is highly speculative, however, because changes in legal aid itself now seem in the offing. ${ }^{41}$ Second, since motorists would face lowered auto insurance premiums under my proposal, it would be fair to impose a modest increase in the driving public's annual road tax-perhaps equal to half of the insurance savings motorists obtain. In this way, although motorists would save overall on their annual costs, they would share some of their potential savings with others. ${ }^{42}$

Third, Government would also benefit under my proposal from a considerable reduction in the need to provide litigation forums for personal injury cases. It may be too much to expect that a great deal of this would be promptly translated into cost savings. More likely outcomes would be speedier and/or more attentive litigation of other cases and a reduced need for more judges over time. The bottom line is that my proposals are not intended to cause a significant increase or decrease in costs to Government. ${ }^{43}$

\footnotetext{
${ }^{40}$ Basic S.S.P. benefits, of course, would continue to be paid for by government. This proposed subsidised insurance arrangement for small employers might, however, take over the administrative responsibilities for paying both basic and enhanced S.S.P.

41 Even under the present scheme such savings are speculative. In practice, nearly all those accident victims who retain a solicitor under the legal aid scheme appear to obtain an award, either by settlement or by judgment. What is unclear is how often, despite the plaintiff's success, legal aid nonetheless winds up with out-of-pocket costs.

It is also worth noting that my proposal will probably require some small increases in legal aid arising from new disputes with employers over non-payment of S.S.P.

42 Another, and perhaps more attractive, way to achieve the same result would be to impose a tax on auto insurance premiums equal to half the cost decrease my reforms bring about.

${ }^{43}$ The reduction in small lawsuits should also modestly benefit government in its role as defendant. In addition, an expanded S.S.P. would apparently generate new income tax revenues and national insurance contributions. In turn however, there would apparently be losses in enterprise income tax where S.S.P. becomes an added cost of business. So, too, there would appear to be a loss of V.A.T. because of the reduced use of lawyers, etc. Yet because of likely offsetting economic effects elsewhere in the economy, I am not at all sure that any of these factors should count in evaluating the wisdom of my proposal.
} 
To review, the projected balance sheet is rather straightforward. Savings are meant to come from reduced litigation costs and reduced pain and suffering awards. New costs are meant to be imposed on larger enterprises that now have poor sickness benefit plans. These sums are to be transferred primarily to workers without good sickness benefits (whether or not they have good tort claims under the present system), to motorists, and to the better functioning of the legal system in other matters.

\section{$V . A$ word about incentives}

Those who are great believers in the power of financial incentives to shape personal behaviour might raise objections to both sides of my proposal. On the one hand, they might be concerned that the weakening of the tort remedy would rob personal injury law of its deterrent power; and on the other, they might fear that the extension of S.S.P. would lead to malingering or even outright fraudulent claims of disability. Although I appreciate the power of these concerns in theory, I don't believe they have important practical force.

In the first place, I have grave doubts about whether the tort system currently makes any important contribution to safe behaviour. ${ }^{44}$ This scepticism is shared by Ison, Pearson and the Oxford group, and is reflected in the outlook of the Consultation Paper as well. Moreover, even if tort law does now deter in some circumstances, I find it hard to imagine that this would change much were a substantial number of the small cases removed from the system-since the threat of liability in the more serious injury cases would remain.

As for behavioural responses to the expanded S.S.P. scheme, there is no reason to think that employers who now have generous O.S.P. plans are suffering from serious problems of malingering or fraud. To be sure, these risks might be somewhat greater with the segment of the workforce now not covered by generous O.S.P. But for those employers who are concerned, an initial waiting period before benefits start (that the expanded S.S.P. scheme would continue to allow), required medical certificates and the like seem to be ample control mechanisms. ${ }^{45}$

\footnotetext{
4 See generally, Sugarman, "Doing Away With Tort Law," (1985) 73 Calif.L.Rev. 555.

is For some empirical support for the view that full wage replacement probably does not present a serious risk of either claimant malingering or an increase in unjustified claims, see J. Creedy and R. Disney, Social Insurance in Transition: An Economic Analysis (1985) at pp.135-138. Although those authors caution that mandating generous employer-provided sick leave gives employers a financial incentive to screen out from among job applicants those who are likely to be future sick leave claimants, I have found no evidence from other countries with good mandatory sick leave benefits demonstrating that this turns out to be a serious problem. Nor, indeed, have I seen proof that British employers with generous occupational sick pay plans have, as a result, acted in a socially perverse way with respect to hiring those with ill health histories. Indeed, Creedy and Disney in the end agree with my conclusion that the present system of low mandatory benefits and selective job-based additions means that there are "arbitrary differences in the treatment of individuals in respect of income replacement . . . Id. at p.138.
} 
In sum, at least in the absence of strong empirical evidence, I don't think that abstract fears about undesirable incentives should stand in the way of what otherwise would seem to be highly attractive reforms.

\section{Analysis by interest group}

This final section briefly considers my proposal for personal injuries law reform in terms of its likely impact on or reception by various interest groups.

A. Poverty and disability groups. Since these groups are concerned about all of the disabled, the enhanced S.S.P. part of my proposal would be a big gain for many of their constituents. Moreover, because most temporarily ill and injured people never have any recourse to tort law, since their disability is not the legal responsibility of any one else, my plan would take away benefits from only a small share of the constituents of these groups. Besides, these organisations typically object to the differential treatment currently given to the disabled on the basis of causal differences in their condition.

To be sure, these groups are quite concerned about the needs of non-earner victims who aren't aided by S.S.P., yet these same people are not now helped with their income needs by tort either. Therefore, even though these disability and poverty organisations, for fear of employer misconduct, generally don't like the privatisation of sick pay arrangements, on balance, they ought to find my proposal quite attractive. ${ }^{46}$

B. Motorists. Car owners ought to like any plan that lowers their liability insurance costs, even if some of that saving is offset by an increase in the road tax or its equivalent.

C. Enterprises. Fewer tort suits would mean that business too would pay less (at least a little less) for tort liability and/or liability insurance. And, although many might be initially concerned that their short run costs would go up as a result of the proposed increase in S.S.P., in fact, a significant proportion of those firms that would have to improve their temporary disability benefits would be small businesses and they would be relieved of the financial burden by the proposed subsidy. Thus, in the end, only a small segment of the business community ought to face cost increases from my proposal, and even those employers ought to be able to make something of the fact that their employees will have much improved sickness benefits. Big business, in general, ought to be pleased that some smaller

\footnotetext{
46 Their support might be assured were the Government to promise extra funding of home help services for the temporarily disabled-the need for which was mentioned in note 23 , supra.
} 
competitors would be brought into line in providing a more generous level of temporary disability benefits.

D. Insurers. Liability insurers would experience a cut back in tort claims, especially auto claims, and this would be very welcome in the short run. Although my proposal would also lead to a reduced volume of insurance premiums, the liability carriers can hardly afford to be seen to favour the current inefficient litigation system.

Casualty insurers might gain new business if the operation of the subsidised S.S.P. insurance pool for small enterprises were contracted out by the Government-which might be quite a good idea.

E. Unions. Labour unions now fight for, and many have achieved, strong O.S.P. plans. Under my proposal generous protection of this sort would become mandatory. It would be hoped that this would be lauded by unions, especially since it would benefit many middle and lower paid employees for whom S.S.P. is inadequate and who have no O.S.P. On the other hand, there is a risk that some union leaders would dislike no longer being able to claim that generous wage replacement during periods of temporary disability was a result of having a strong union. Still, as many unions now seem to support S.S.P. ${ }^{47}$ they ought to favour its extension.

F. Lawyers. The work of some lawyers, of course, would be sharply curtailed were my reforms adopted. They could be counted on to become outspoken critics of the proposals. An expected argument would be that the S.S.P. expansion should be adopted without the rest of the package. But unless there is to be a big drop in the use of litigation in personal injuries cases, a central purpose of the reform is defeated. At the same time, it should not be forgotten that the profession as a whole might welcome the reform of a system that I suspect is increasingly embarrassing to many lawyers.

\footnotetext{
47 See, e.g. Statutory Sick Pay, supra, note 14, at pp.49-50.
} 